Carbon uptake and carbon

\title{
Temperature and phytoplankton cell size regulate carbon uptake and carbon overconsumption in the ocean
}

\section{S. E. Craig ${ }^{1}$, H. Thomas ${ }^{1}$, C. T. Jones ${ }^{1}$, W. K. W. Li ${ }^{2}$, B. J. W. Greenan ${ }^{2}$, E. H. Shadwick ${ }^{3}$, and W. J. Burt ${ }^{1}$}

${ }^{1}$ Department of Oceanography, Dalhousie University, 1355 Oxford Street, P.O. Box 15000, Halifax, Nova Scotia, B3H 4R2, Canada

${ }^{2}$ Bedford Institute of Oceanography, Department of Fisheries and Oceans, Dartmouth, Nova Scotia, B2Y 4A2, Canada

${ }^{3}$ Antarctic Climate \& Ecosystems Cooperative Research Centre, University of Tasmania, Hobart, Tasmania, Australia

Received: 20 June 2013 - Accepted: 24 June 2013 - Published: 8 July 2013

Correspondence to: S. E. Craig (susanne.craig@dal.ca)

Published by Copernicus Publications on behalf of the European Geosciences Union.

\section{overconsumption in \\ the ocean \\ S. E. Craig et al.}

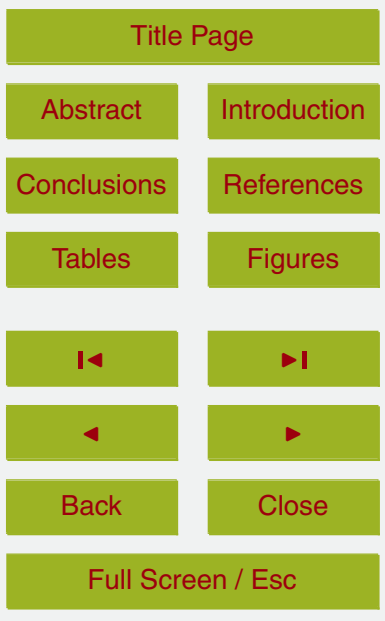

Printer-friendly Version

Interactive Discussion 


\section{Abstract}

Phytoplankton plays a critical role in the uptake of atmospheric carbon dioxide by the ocean, and is comprised of a spectrum of cell sizes that are strongly associated with different oceanographic conditions. Studies suggest that the ocean will become in-

creasingly stratified in response to a warming climate, limiting nutrient exchange to the upper sunlit ocean and favouring small cells able to grow in warmer, nutrient poor conditions. Here we show that, in a temperate shelf sea, a summertime population of numerically abundant small cells accounts for approximately $20 \%$ of annual carbon uptake. These small cells are not well represented by chlorophyll $a-$ the ubiquitously used proxy of phytoplankton biomass - but rather, are strongly correlated with surface water temperature. Given the persistent near-zero nutrient concentrations during the summer, it appears that small cells drive carbon overconsumption, and suggest that their role in carbon fixation will become increasingly important in a warming ocean.

\section{Introduction}

15 Accounting for approximately half of annual global primary production (Falkowski et al., 1998), phytoplankton exert a fundamental control on the uptake of carbon dioxide $\left(\mathrm{CO}_{2}\right)$ by the ocean and thus, atmospheric $\mathrm{CO}_{2}$ concentration. The growth of phytoplankton is largely controlled by water column structure that regulates the availability of nutrients through mixing and stratification and light via the turbulent mixing of cells throughout the euphotic zone. Recent investigations have pointed to the effects of increasing water column stratification on oceanic phytoplankton communities, caused by an ensemble of processes associated with global climate change (Cermeño et al., 2008; Li et al., 2009; Riebesell et al., 2009; Morán et al., 2010; Taucher and Oschlies, 2011). These studies show a change in the phytoplankton community size structure towards smaller cells apparently in response to the impoverished nutrient conditions resulting from stronger stratification which limits mixing of nutrients from deeper waters
BGD

10, 11255-11282, 2013

Carbon uptake and carbon

overconsumption in the ocean

S. E. Craig et al.

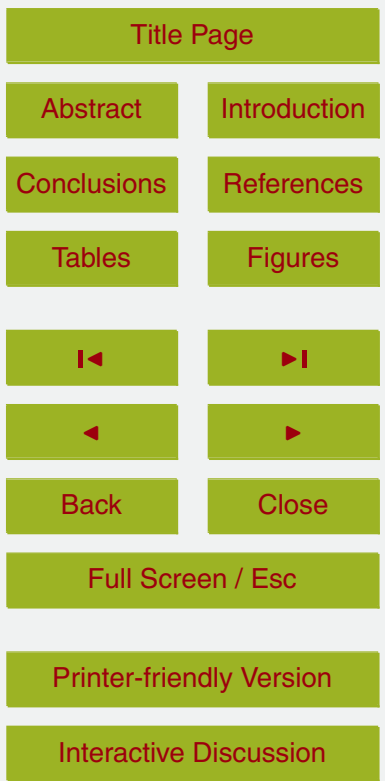


into the euphotic zone. An alteration of phytoplankton size structure has profound implications for energy transfer to higher trophic levels. Longer food chains, and therefore decreased energy transfer efficiency to higher trophic levels, are associated with assemblages dominated by small cells (Barnes et al., 2011), and a relationship between 5 fish production and nutrient-controlled cell size has been suggested (Sommer et al., 2002). Export of carbon from the surface ocean has also been shown to be strongly dependent on phytoplankton cell size; larger cells tend to be dominant in higher nutrient and turbulence regimes (Margalef, 1978) and are associated with greater sinking rates, higher cellular carbon values and, consequently, greater carbon export to the 10 deep ocean (Laws et al., 2000; Finkel et al., 2010). Yet, how such a climate-driven alteration of phytoplankton size structure might affect the biologically mediated uptake of atmospheric $\mathrm{CO}_{2}$ by the ocean has rarely been explored. In this report we utilize observations from a "natural laboratory" provided by a long-term study site on the Scotian Shelf in the western North Atlantic. Over an annual cycle, observations at this site encompass a dramatic warming of surface waters from sub-zero to $\sim 20^{\circ} \mathrm{C}$ and the concomitant response of the phytoplankton community, thus providing an analogue of the physical and biological responses of the upper ocean likely to result from climateinduced warming.

\section{Materials and methods}

\subsection{In situ data}

Phytoplankton, chemical, hydrographic and partial pressure of $\mathrm{CO}_{2}\left(p \mathrm{CO}_{2} ; \mu a t m\right)$ data were collected from station HL2 $\left(44.4^{\circ} \mathrm{N}-63.3^{\circ} \mathrm{W}\right)$ on the Scotian Shelf, eastern Canada (Fig. 1), a site of regular monitoring since 1998 by the Department of Fisheries and Oceans (DFO) Canada as part of the Atlantic Zone Monitoring Program (AZMP; http://www.bio.gc.ca/science/monitoring-monitorage/azmp-pmza-eng.php). Sampling methods, experimental procedures and methods have been described in detail pre-
BGD

10, 11255-11282, 2013

Carbon uptake and carbon

overconsumption in the ocean

S. E. Craig et al.

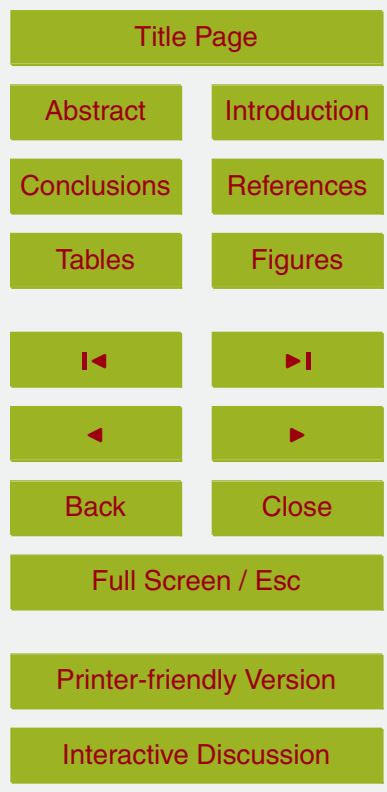


viously (Li and Dickie, 2001; Li and Harrison, 2001; Shadwick et al., 2011). Briefly, high temporal resolution measurements of $\mathrm{pCO}_{2}$ at approximately $2 \mathrm{~m}$ were obtained from a CARIOCA buoy moored at station HL2. Ship-based measurements were also collected bi-weekly from station HL2 and included CTD casts, microscopic enumer5 ation of microphytoplankton $(20-200 \mu \mathrm{m})$ and water sample analyses for chlorophyll a concentration ( $\mathrm{Chl} \mathrm{a} ; \mathrm{mg} \mathrm{m}^{-3}$ ) and nutrients using the methodologies detailed by Mitchell et al. (2002b). Flow cytometric counts of pico- $(0.2-2 \mu \mathrm{m})$ and nanophytoplankton $(2-20 \mu \mathrm{m})$ measured weekly at a nearby coastal monitoring site in Bedford Basin $\left(44.69^{\circ} \mathrm{N},-63.64^{\circ} \mathrm{W}\right)$ were used as proxies for the abundance of these size fractions 10 at HL2. The use of these counts as proxies for HL2 was considered robust as previous studies have demonstrated that they are temporally coherent with the less frequent measurements of the same size fractions made at HL2 (Li et al., 2006; Li and Harrison, 2008). Monthly climatologies were then constructed for each of these parameters.

The spectral phytoplankton absorption coefficient $\left(a_{\mathrm{ph}}(\lambda) ; \mathrm{m}^{-1}\right)$ was also measured 15 at HL2 and the wider Scotian Shelf region approximately 2-3 times per year using the quantitative filter technique (Mitchell et al., 2002a) and a pathlength amplification factor derived by Hoepffner and Sathyendranath $(1992,1993)$ and modified by Kyewalyanga et al. (1998).

\subsection{Satellite data and derived products}

20 MODIS Aqua level 2 LAC $1 \mathrm{~km}$ remote sensing reflectance spectra $\left(R_{\mathrm{rs}}(\lambda)\right.$; sr $\left.{ }^{-1}\right)$ of the Scotian Shelf region were downloaded from http://oceancolor.gsfc.nasa.gov/. A regionally tuned version of the Craig et al. (2012) ocean colour model to estimate phytoplankton absorption spectra was derived using the satellite $R_{\mathrm{rs}}(\lambda)$ spectra and in situ $a_{\text {ph }}(\lambda)$ measurements (see Supplement). The resulting model was then used to derive $a_{\mathrm{ph}}(\lambda)$ from MODIS Aqua level 3 mapped $4 \mathrm{~km}$ monthly composites of $R_{\mathrm{rs}}(\lambda)$ (http://oceandata.sci.gsfc.nasa.gov/MODISA/Mapped/Monthly/4km/Rrs/) in a box encompassing station HL2 but not beyond the shelf break: $43.5^{\circ} \mathrm{N} \leq$ latitude $\leq 45^{\circ} \mathrm{N}-$ $65^{\circ} \mathrm{W} \leq$ longitude $\leq-63^{\circ} \mathrm{W}$. All ocean colour derived parameters reported are the av-
BGD

10, 11255-11282, 2013

Carbon uptake and carbon

overconsumption in the ocean

S. E. Craig et al.

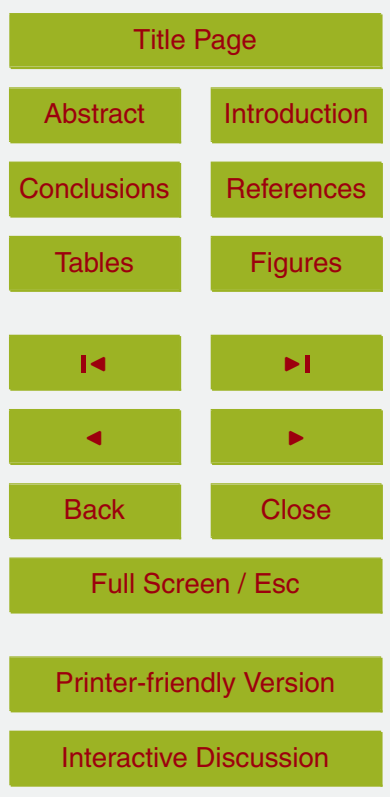

Interactive Discussion 
erage of this box. Additionally, Pathfinder 5 AVHRR $4 \mathrm{~km}$ sea surface temperature $\left(\mathrm{SST} ;{ }^{\circ} \mathrm{C}\right)$ for station HL2 was downloaded from the Bedford Institute of Oceanography database (http://www.bio.gc.ca/science/data-donnees/base/data-donnees/ssteng.php).

\section{$5 \quad 3$ Results and discussion}

\subsection{Phytoplankton size class seasonal patterns}

The annual spring bloom in the western North Atlantic typically occurs during late March to early April at the temperature minimum and mixed layer depth maximum (Fig. 2), and, over the period of just a few weeks, draws down approximately one third 10 of the total carbon fixed over the annual cycle in this region (Fournier et al., 1977). During the intense carbon uptake of the spring bloom, diatoms in the microphytoplankton $(20-200 \mu \mathrm{m})$ size range dominate the phytoplankton assemblage (Fig. 3a, b). These cells are adapted to rapid growth in the nutrient replete conditions (Fogg, 1991) that result from intense winter mixing, and reach their climatological maximum of

$152.4 \times 10^{8}$ cells m$^{-3}$ in April. The spring bloom collapses precipitously when nitrate and silicate are largely depleted (Fig. 2c, d), and beginning May, a new assemblage of cells dominated by much smaller but numerically more abundant pico- $(0.2-2 \mu \mathrm{m})$ and nanophytoplankton $(2-20 \mu \mathrm{m})$ flourish in the warming, relatively nutrient poor conditions (Figs. 2 and 3). Pico- and nanophytoplankton cell abundance increases steadily, reaching its maximum of $10 \times 10^{10}$ cells m$^{-3}$ in September. This seasonal pattern is mirrored in the dinoflagellate population, although their abundance is approximately four orders of magnitude less than the pico- and nanophytoplankton fraction. Dinoflagellates are generally categorized in the microphytoplankton size class, and, in the context of size scaling with temperature (Peters, 1983), their co-occurrence with the smaller cell sizes seems incongruous. However, dinoflagellates possess a collection of unique features (e.g. mixotrophy and the ability to vertically migrate (Smayda, 1997)), which

Carbon uptake and carbon

overconsumption in the ocean

S. E. Craig et al.

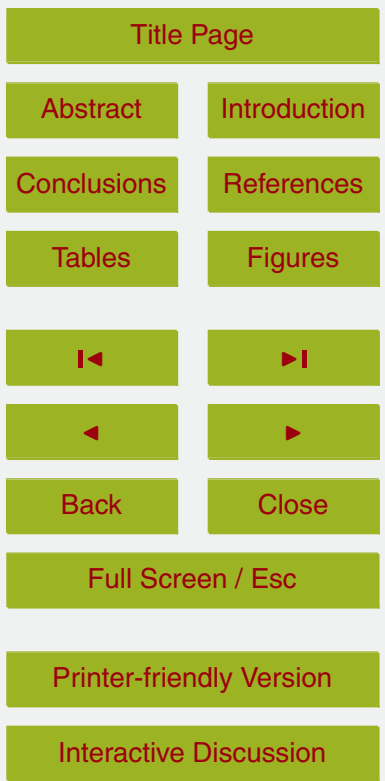


collectively may reduce their dependence on nutrients delivered from aphotic depths increasing the likelihood of peak abundance during the summer months.

Following the spring bloom, the diatom contribution to total cell abundance remains low at $<0.5 \times 10^{8}$ cells $\mathrm{m}^{-3}$, although occasionally, a modest autumnal bloom occurs 5 caused by wind-driven mixing (Greenan et al., 2004), and this is reflected in the small elevation in the diatom climatology in November (Fig. 3a, b). It should be noted that, despite being numerically more abundant than diatoms by several orders of magnitude in the summer months, pico- and nanophytoplankton biomass is not correlated with chlorophyll a standing stock (Fig. 3c), an important observation also made by Claustre 10 (1994) in several oceanic provinces. Chl $a$ is persistently less than $1 \mathrm{mg} \mathrm{m}^{-3}$ following the collapse of the spring bloom, yet the cell counts reveal substantial biomass in the pico- and nanophytoplankton fractions, emphasizing the fact that $\mathrm{Chl}$ a primarily mirrors patterns in the diatom fraction of the assemblage (Fig. 3d), but not the dinoflagellate fraction (Fig. $3 e$ ). For this reason, the assumption that $\mathrm{Chl} a$ is a robust proxy for biomass should be applied with care (Cullen, 1982).

\subsection{Characterisation of community composition from satellite ocean colour}

The shape of $a_{\mathrm{ph}}(\lambda)$ is strongly related to phytoplankton size (Bricaud et al., 2004), which in turn, can be related to trophic state (Chisholm, 1992), making it a powerful means to detect the transition from diatom dominated assemblages in the spring to 20 pico- and nanophytoplankton dominated assemblages in the summer. To investigate the potential of satellite measurements to reveal phytoplankton size class information, $a_{\mathrm{ph}}(\lambda)$ was first derived from MODIS Aqua level 2 LAC $1 \mathrm{~km} R_{\mathrm{rs}}(\lambda)$ from the Scotian Shelf region using a regionally trained ocean colour algorithm (Craig et al., 2012) (See Supplement). The model of Ciotti et al. (2002) was then used to estimate a dimensionless size factor $\left(S_{f}\right)$ from the satellite-derived $a_{\mathrm{ph}}(\lambda)$ from the Scotian Shelf. $S_{f}$ is essentially derived from a spectral mixing model parameterised by two absorption spectra - one from very small picophytoplankton and the second from very large microphytoplankton. The model additively combines these two spectra and $S_{f}$ specifies

Carbon uptake and carbon

overconsumption in the ocean

S. E. Craig et al.

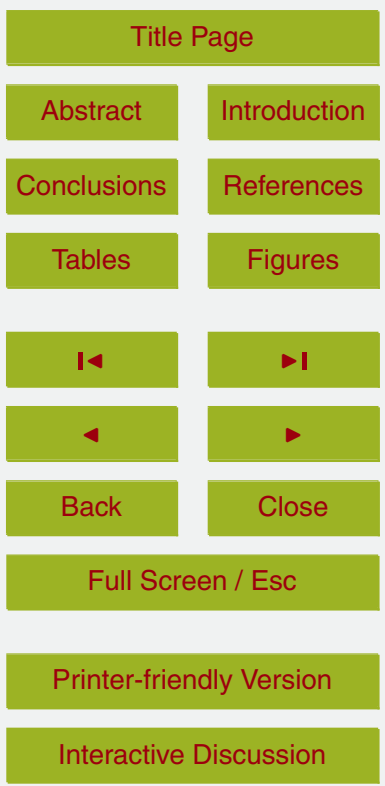


the complementary contribution of each, where $S_{f}$ values close to 0 indicate an assemblage entirely dominated by microphytoplankton, $S_{f}$ values close 1 an assemblage dominated by picophytoplankton, and intermediate values the mixture of size classes typically found in natural phytoplankton assemblages (Ciotti et al., 2002; Ciotti and

5 Bricaud, 2006). The satellite-derived $S_{f}$ was compared with $S_{f}$ derived from matching in situ filterpad $a_{\mathrm{ph}}(\lambda)$ to ensure that no bias or errors were introduced by using satellitederived $a_{\text {ph }}(\lambda)$ (Fig. 4a). The two values were found to agree well $\left(R^{2}=0.763, N=54\right.$, RMSE $=0.065)$, and satellite-derived $S_{f}$ was considered to be a reliable means of describing the dominant size class of the phytoplankton assemblage. The $S_{f}$ model was then applied to $a_{\mathrm{ph}}(\lambda)$ spectra derived from monthly climatological $R_{\mathrm{rs}}(\lambda)$ (MODIS Aqua level 3 mapped $4 \mathrm{~km}$ monthly $R_{\mathrm{rs}}(\lambda)$ composites) from the HL2 box. $S_{f}$ is observed to mirror clearly the patterns revealed by the in situ data (Fig. 3b) - larger cells dominate the phytoplankton assemblage in the spring $\left(S_{f}<0.1\right)$, smaller cells in the summer months $\left(S_{f} \approx 0.3\right)$ and an intermediate size around the autumnal bloom $\left(S_{f} \approx 0.26\right)$. have been successfully implemented to delineate phytoplankton community composition (Alvain et al., 2005; Uitz et al., 2006; Brewin et al., 2011; Devred et al., 2011; Hirata et al., 2011), and the success at this study site highlights the potential utility of remote sensing in revealing synoptic seasonal patterns in phytoplankton succession.

\subsection{Cell size and carbon uptake}

Phytoplankton cell counts (cells $\mathrm{m}^{-3}$ ) were converted into total cellular carbon concentration $\left(\mathrm{mol} \mathrm{C} \mathrm{m}^{-3}\right.$ ) using average literature values for carbon content per cell for pico-, nano- and microphytoplankton (Mullin et al., 1966; Verity et al., 1992; Li et al., 1993; Menden-Deuer and Lessard, 2000; Li and Harrison, 2001). These values were then used to examine the relationship between water temperature and phytoplankton carbon concentration (Fig. 5a). We present temperature on the abscissa rather than date to account for the fact that the same temperature may occur in multiple seasons. Max-
BGD

10, 11255-11282, 2013

Carbon uptake and carbon

overconsumption in the ocean

S. E. Craig et al.

Title Page

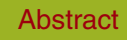

Introduction

Conclusions

Tables

References

Figures

14

4

Back

Full Screen / Esc

Printer-friendly Version

Interactive Discussion 
imum phytoplankton carbon concentration is observed at the temperature minimum during the diatom dominated spring bloom. Minimum phytoplankton carbon concentrations occur at approximately $5^{\circ} \mathrm{C}$, corresponding to both the collapse of spring bloom ( May) and early winter (December/January). Over the post spring bloom warming 5 period $\left(\sim 5-20^{\circ} \mathrm{C} \approx\right.$ May-August, Figs. 2 and 3), phytoplankton carbon concentration, in concert with pico- and nanophytoplankton abundance, steadily increases by $\sim 85 \%$ attaining values comparable to the those in the spring (Fig. 5a). Throughout this period, Chl $a$ is persistently $<1 \mathrm{mg} \mathrm{m}^{-3}$ (Fig. 3b), reinforcing the fact that this important fraction of the phytoplankton assemblage is almost completely decoupled from the chlorophyll standing stock (Fig. 3c; c.f. Claustre, 1994) - significant given the fact that Chl $a$ is used ubiquitously as the biomass term in many different types of global and regional ocean models (e.g. Behrenfeld et al., 2006; Fennel et al., 2008; Boyce et al., 2010). The inability to accurately estimate carbon uptake from $\mathrm{Chl}$ a during this summer period was also identified by Shadwick and colleagues (Shadwick et al., 2010, 2011), and reinforces the concept that Chl a closely mirrors the patterns of assemblages with high intracellular Chl a, e.g. large diatoms (Li et al., 2006) (Fig. 3b, d), but does not accurately represent the more numerically abundant smaller size fractions with lower intracellular Chl a that dominate in the summer months (Fig. 3c).

To resolve the important contribution of seasonal biological signals to total carbon dynamics, phytoplankton net community production $\left(\mathrm{NCP}_{\mathrm{p}} ; \mathrm{mol} \mathrm{Cm}^{-3} \mathrm{month}^{-1}\right)$ was calculated from the rate of change of phytoplankton carbon concentration from month to month, i.e. $\mathrm{NCP}_{\mathrm{p}}=C_{\mathrm{p}}\left(t_{2}\right)-C_{\mathrm{p}}\left(t_{1}\right) /\left(t_{2}-t_{1}\right)$, where $C_{\mathrm{p}}\left(t_{x}\right)$ is phytoplankton carbon concentration at time $x\left(t_{2}>t_{1}\right)$, and where positive values represent an increase in phytoplankton carbon concentration (Fig. 5b). The error bars represent one standard deviation of total $\mathrm{NCP}_{p}$, calculated from the mean of 1999-2011, and indicate the high degree of interannual variability. The $\mathrm{NCP}_{\mathrm{p}}$ maximum of $0.12 \mathrm{~mol} \mathrm{Cm}^{-3}$ month $^{-1}$ occurs in April and is influenced primarily by the rapid increase in diatom cell numbers during the spring bloom. This compares well to $\mathrm{pCO}_{2}$-derived springtime values for NCP of $0.08 \mathrm{~mol} \mathrm{C} \mathrm{m}^{-3}$ month $^{-1}$ found by both Shadwick et al. (2011) and Thomas
BGD

10, 11255-11282, 2013

Carbon uptake and carbon

overconsumption in the ocean

S. E. Craig et al.

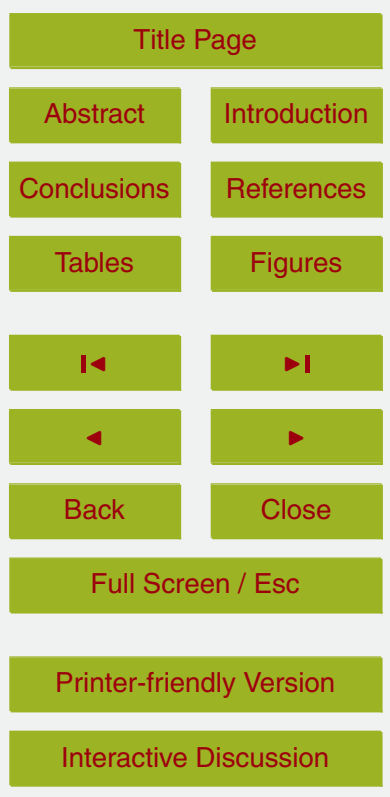


et al. (2012) at this site and represented in Fig. 5b as S2011 and T2012 respectively. The precipitous decrease in diatom abundance in May drives $\mathrm{NCP}_{\mathrm{p}}$ to a negative value of $-0.15 \mathrm{~mol} \mathrm{Cm}^{-3}$ month $^{-1}$, similar in absolute magnitude to the spring value. $\mathrm{NCP}_{\mathrm{p}}$ is positive throughout June-September reflecting the steady increase in picophytoplank5 ton, nanophytoplankton and dinoflagellate abundance, which, along with temperature, reach their maxima in September (Fig. 2a). An average of the positive $\mathrm{NCP}_{\mathrm{p}}$ values during June-September gives $0.034 \mathrm{~mol} \mathrm{C}^{-3} \mathrm{month}^{-1}$, a value comparable to the average of summertime NCP computed by Shadwick et al. (2011) $\left(0.017 \mathrm{~mol} \mathrm{Cm}^{-3}\right.$ month ${ }^{-1}$ ). Integrating the positive summertime $\mathrm{NCP}_{\mathrm{p}}$ values (i.e. $\int_{\text {June }}^{\text {September }} \mathrm{NCP}_{\mathrm{p}}(t) \mathrm{d} t$ ) 10 yields a phytoplankton carbon concentration of $0.14 \mathrm{~mol} \mathrm{C} \mathrm{m}^{-3}$, slightly greater than the $0.12 \mathrm{~mol} \mathrm{C} \mathrm{m}^{-3}$ value in April associated with the spring bloom. If the entire mixed layer depth, (MLD; $\mathrm{m}$ ) is considered, i.e. an $\mathrm{NCP}_{\mathrm{p}}$ inventory, $\mathrm{NCP}_{\mathrm{p}}^{\prime}\left(\int_{0}^{\mathrm{MLD}} \mathrm{NCP}_{\mathrm{p}}(z) \mathrm{d} z=\mathrm{NCP}_{\mathrm{p}}^{\prime}\right.$; mol C m${ }^{-2}$ month $^{-1}$ ), then average summer $\mathrm{NCP}_{\mathrm{p}}^{\prime}$ is $3.81 \mathrm{~mol} \mathrm{Cm}^{-2} \mathrm{month}^{-1}$ and integrated summer $\mathrm{NCP}_{\mathrm{p}}^{\prime}\left(=\int_{\text {June }}^{\text {September }} \int_{0}^{\mathrm{MLD}} \mathrm{NCP}_{\mathrm{p}} \mathrm{d} t \mathrm{~d} z\right)$ is $15.26 \mathrm{~mol} \mathrm{Cm}^{-2}$, representing $158 \%$ and $32 \%$ of the spring bloom $\mathrm{NCP}_{\mathrm{p}}^{\prime}\left(48.32 \mathrm{~mol} \mathrm{Cm}^{-2}\right.$ month $\left.^{-1}\right)$ respectively. Summing all of the positive $\mathrm{NCP}_{\mathrm{p}}^{\prime}$ values yields an annual value of $90.47 \mathrm{~mol} \mathrm{Cm}^{-2}$. Comparing integrated summer $\mathrm{NCP}_{p}^{\prime}\left(=15.26 \mathrm{~mol} \mathrm{Cm}^{-2}\right)$ to the annual value reveals that the summer phytoplankton assemblage accounts for $\sim 17 \%$ of annual uptake of carbon, and reinforces the fact that summertime productivity is significant. Most impor20 tantly, two rates of carbon uptake can be delineated: a spring $\mathrm{NCP}_{\mathrm{p}}$ of $0.12 \mathrm{~mol} \mathrm{~m}^{-3}$ month $^{-1}$ associated with a microphytoplankton diatom assemblage, and an average summer $\mathrm{NCP}_{\mathrm{p}}$ of $0.034 \mathrm{~mol} \mathrm{C} \mathrm{m}^{-3}$ month $^{-1}$ associated with a pico- and nanophytoplankton dominated assemblage.

A composite seasonal cycle of $p \mathrm{CO}_{2}$ constructed from data spanning 2007-2009 25 is shown in Fig. 5c. To account for the effect of water temperature, we present $p \mathrm{CO}_{2}$ corrected to a constant annual mean temperature $\left(p \mathrm{CO}_{2}\right.$, norm; $\mu$ atm) (c.f. Takahashi et al., 2002; Shadwick et al., 2011). The seasonal evolution and succession of the

BGD

10, 11255-11282, 2013

Carbon uptake and carbon

overconsumption in the ocean

S. E. Craig et al.

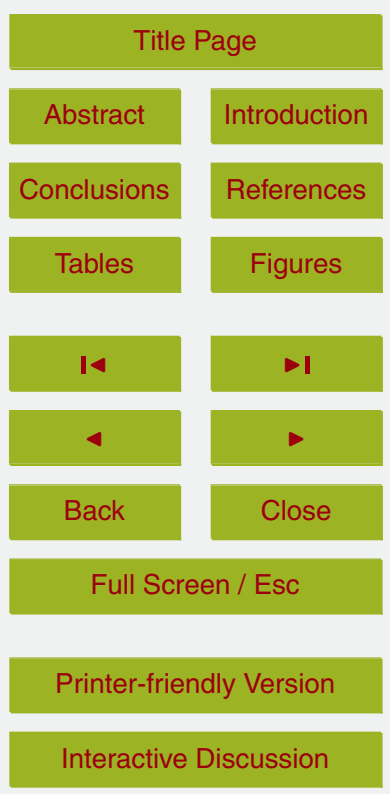


different phytoplankton communities is clearly evident in the bulk $\mathrm{CO}_{2}$ system parameters. Springtime maximum phytoplankton carbon concentration, which is associated with large diatoms and high $\mathrm{NCP}_{p}$ values (Figs. 5a, b, 3a, b) and that occurs at the temperature minimum, is reflected in the rapid drop in $p \mathrm{CO}_{2}$, norm (Fig. $5 \mathrm{a}, \mathrm{c}$ ). The col5 lapse of the bloom and the onset of surface warming in May results in rising $p \mathrm{CO}_{2}$, norm concentrations, and at a water temperature of $\sim 5-6^{\circ} \mathrm{C}$ in May/June, the diatom community is succeeded by smaller pico- and nanophytoplankton and dinoflagellates associated with lower $\mathrm{NCP}_{\mathrm{p}}$ values (Figs. $3 \mathrm{a}, \mathrm{b}, 5 \mathrm{~b}$ ). The increase in biomass and concomitant uptake of carbon by these communities (Fig. 5a) consistently lowers $p \mathrm{CO}_{2}$, norm 10 (Fig. 5c) throughout the summer months until the temperature reaches its maximum. At the end of the summer period, respiration resulting from decay of phytoplankton biomass (Fig. 5a) and wind-induced or convective entrainment of $\mathrm{CO}_{2}$ from deeper waters (Greenan et al., 2004) raises $p \mathrm{CO}_{2}$, norm back to pre-bloom winter conditions.

\subsection{Satellite estimates of $\mathrm{NCP}_{\mathrm{p}}$}

Having shown the strong effect of seasonal phytoplankton succession on the drawdown of $p \mathrm{CO}_{2}$ on in situ single point measurements, an obvious question that arises is whether remotely sensed satellite data can be used to predict $\mathrm{NCP}_{\mathrm{p}}$. It was clearly shown in the preceding sections that $\mathrm{Chl} a$ is a poor proxy of small cell biomass (Fig. 3c) making it an unsuitable remote sensing parameter for estimating biologically mediated carbon drawdown - especially in the summer. However, studies performed in the North Atlantic have shown that water temperature can be used as a holistic simplifier of mechanistically complex processes (e.g. the response of phytoplankton to seasonal variability in nutrients and mixed layer depth) and can predict the abundance of pico- and nanophytoplankton (Li et al., 2006; Morán et al., 2010). We use the same approach and examine the relationship between $\log _{10}$ [picophytoplankton + nanophytoplankton] abundance and water temperature at HL2 during 1999-2011 (Fig. 6a) to reveal a strong correlation $\left(R^{2}=0.739, N=156, p \ll 0.01\right)$, comparable to the findings of previous studies at other North Atlantic sites (Li et al., 2006; Morán et al., 2010). Temperature

Carbon uptake and carbon

overconsumption in the ocean

S. E. Craig et al.

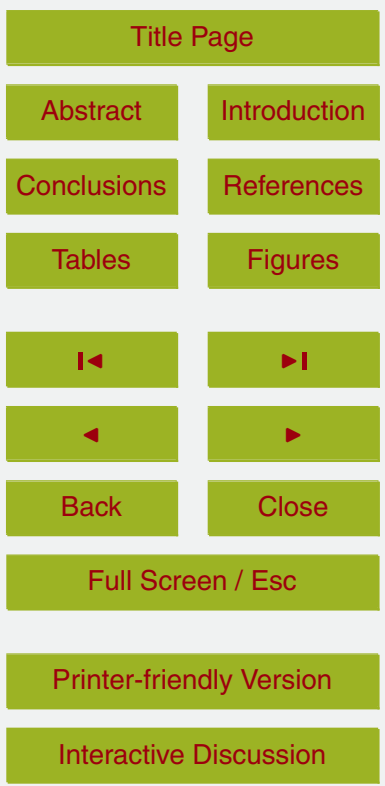


was also found to predict the $\log _{10}$ abundance of dinoflagellates, but this relationship was revealed only when the data were organised into climatological months. The resulting regression equation for estimating dinoflagellate abundance $\left(\widehat{y}_{\text {dino }}\right.$; cells $\left.\mathrm{m}^{-3}\right)$ was $\widehat{y}_{\text {dino }}=10^{6.300+0.0378 T}\left(R^{2}=0.819, N=12, p \ll 0.01\right)$, where $T$ is water tempera5 ture $\left({ }^{\circ} \mathrm{C}\right)$. In the case of diatoms, there is essentially no relationship between temperature and $\log _{10}$ abundance as diatom peak abundance is during the spring bloom that occurs prior to appreciable increase in water temperature (Fig. 3b). Instead, diatom abundance $\left(\widehat{y}_{\text {dia }}\right.$; cells $\left.\mathrm{m}^{-3}\right)$ was estimated using the following simple relationship:

$\widehat{y}_{\text {dia }}=\frac{\text { dia }_{\text {clim }}}{(\text { pico }+ \text { nano })_{\text {clim }}} \cdot \widehat{y}_{\text {pico+nano }}$

10 where dia $_{\text {clim }}$ and (pico + nano) $)_{\text {clim }}$ are the climatological cell concentrations for diatoms and (picophytoplankton + nanophytoplankton) respectively and $\widehat{y}_{\text {pico+nano }}$ is estimated using the regression in Fig. $6 a$.

Cell abundances were estimated from Pathfinder 5 AVHRR $4 \mathrm{~km}$ satellite measurements of SST from station HL2 using the relationships described above, converted 15 to cellular carbon using literature carbon cell $^{-1}$ values, then used to calculate satellite $\mathrm{NCP}_{\mathrm{p}}\left(\mathrm{NCP}_{\mathrm{psat}} ; \mathrm{molCm}^{-3} \mathrm{month}^{-1}\right)$ for the period 1999-2010 (Fig. 6b). We note here that a strong relationship $\left(R^{2}=0.961, N=12, p \ll 0.01\right)$ was found for monthly climatological values of $\log _{10}$ [picophytoplankton + nanophytoplankton] abundance, but it was decided to use the fully time resolved monthly data (1999-2011) as this produced the best estimates of $\mathrm{NCP}_{\text {psat }}$ (see below), likely due to the fact that more of the variance was accounted for. It is evident that the performance of this approach is variable, with satisfactory estimates $\left(R^{2}>0.5\right)$ of $\mathrm{NCP}_{\text {psat }}$ obtained for only some of the years or portions of those years. In order to estimate the error associated with each $\mathrm{NCP}_{\text {psat }}$ calculation step, statistics are presented in Table 1 to describe the agreement between $\mathrm{NCP}_{\mathrm{p}}$ and $\mathrm{NCP}_{\text {psat }}$ for the total phytoplankton assemblage (tot) and for each of the assemblage components ( $p+n-$ (picophytoplankton + nanophytoplankton); dia - diatoms; dino - dinoflagellates). $R_{\text {tot }}^{2}$ is greater than 0.5 for 5 out of the $12 \mathrm{yr}(1999$, 11265
BGD

10, 11255-11282, 2013

Carbon uptake and carbon

overconsumption in the ocean

S. E. Craig et al.

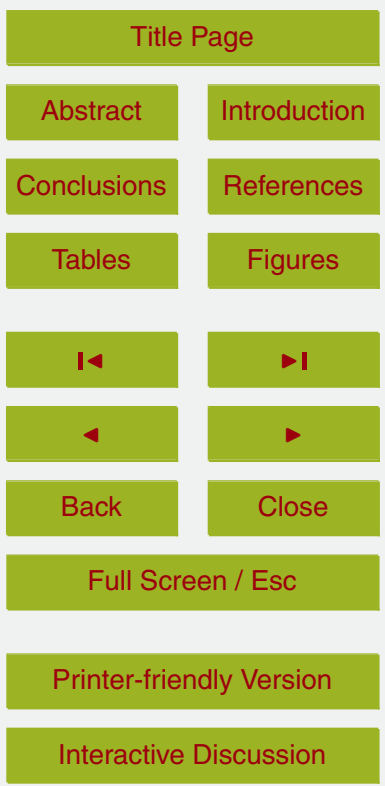


2000, 2001, 2005 and 2008), although 2001 and 2005 have in situ data points for only $\sim$ one half of the year. $R_{p+n}^{2}$ is greater than 0.5 for almost the same subset of years (with the exception of 2001), illustrating the importance of robust $p+n$ estimates for accurate estimation of $\mathrm{NCP}_{\text {psat }} . R_{\text {dino }}^{2}$ is never greater than 0.5 , even in the years for which

5 reasonably accurate $\mathrm{NCP}_{\text {psat }}$ estimates (i.e. $R_{\text {tot }}^{2}>0.5$ ) were obtained. Compared to the contribution in abundance terms of diatoms in the spring and pico- and nanophytoplankton in the summer, the contribution to $\mathrm{NCP}_{\mathrm{p}}$ from dinoflagellates is small $(\sim 4 \%$ maximum) and could likely be omitted from these calculations with little or no impact on $\mathrm{NCP}_{\text {psat }}$ accuracy (see statistics for $p+n+$ dia in Table 1 ). Interestingly, $\widehat{y}_{\text {dia }}$ is rather 10 accurately estimated $\left(R_{\text {dia }}^{2} \approx 0.5-0.9\right)$ in most years - surprising given the simple climatological ratio method used to estimate diatom abundance and suggestive of a fairly stable ratio of diatoms to $p+n$ from year to year. It is presently unclear why the approach works reasonably well for some years but not for others. Temperature is used here as a means to integrate many complex mechanisms and their resulting effects on small cell abundance, and it is clear that the relationship breaks down under certain conditions that are not resolved by our analyses. However, as a preliminary exercise, the approach does show promise, is comparable in terms of accuracy of $\mathrm{NCP}_{p}$ estimates to other approaches (e.g. Serret et al., 2009) and points to the potential utility of satellite measurements to provide synoptic scale insight into the biological mediation of carbon. This approach could be particularly useful during the summer season when Chl $a$, typically $<1 \mathrm{mg} \mathrm{m}^{-3}$ at this site and the surrounding shelf area, is not representative of the small cell biomass and its associated and significant carbon uptake.

\subsection{Carbon overconsumption and temperature effects}

The increase in phytoplankton biomass, and thus $\mathrm{NCP}_{\mathrm{p}}$, during the summer months 25 is in spite of apparent depletion of surface mixed layer nitrate (Fig. 2c), a finding also reported at this site by Shadwick and colleagues (Shadwick and Thomas, 2011; Shadwick et al., 2011). They observed supersaturation of $\mathrm{O}_{2}$ with respect to atmospheric

Carbon uptake and carbon

overconsumption in the ocean

S. E. Craig et al.

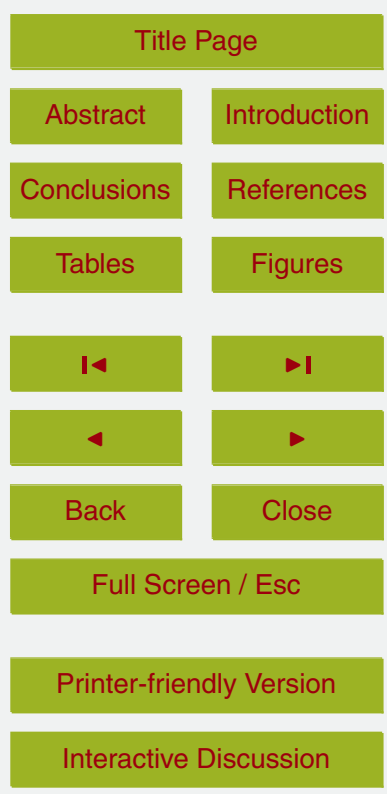


levels and a decrease in DIC in surface waters at HL2 throughout the post bloom summer months, which they attributed to phytoplankton primary production. The phenomenon of elevated carbon consumption relative to nitrogen that exceeds the classical Redfield ratio (Redfield et al., 1963) of 6.6 - so called "carbon overconsumption" 5 - has been reported extensively in the literature (Sambrotto et al., 1993; Toggweiler, 1993; Thomas et al., 1999; Osterroht and Thomas, 2000; Körtzinger et al., 2001; Koeve, 2004; Taucher et al., 2012; Jiang et al., 2013), and the authors of these studies observed that overconsumption appears to be associated with summertime nutrient poor conditions. Here, we place overconsumption of carbon in the context of the seasonal succession of phytoplankton size classes, that can be related to trophic state (Chisholm, 1992), and that is governed by the paradigm described by Margalef of organisms of differing sizes inhabiting specific regions of turbulence-nutrient space (Margalef, 1978). We postulate that, given the persistent near zero nitrate concentrations present in the summer months (Fig. 2c), the pico- and nanophytoplankton dominated assemblage is responsible for carbon overconsumption and achieves this by intensive recycling of biomass degradation products (e.g. $\mathrm{NH}_{4}^{+}$) and, perhaps, also by bacterivory (Zubkov and Tarran, 2008).

The effect of temperature on NCP for pico- and nanophytoplankton $\left(\mathrm{NCP}_{\mathrm{p}+n}\right)$, and thus on overconsumption, was examined by plotting the annual summer maxima during 1999-2010 for $\mathrm{NCP}_{\mathrm{p}+\mathrm{n}}$ and for water temperature (Fig. 7a), which revealed a positive correlation $\left(R^{2}=0.412, N=11, p<0.05\right)$. This effect was further explored through a simple exercise in which $0.5^{\circ} \mathrm{C}, 1^{\circ} \mathrm{C}$ and $2{ }^{\circ} \mathrm{C}$ were added to the climatological seasonal temperature cycle, and found to increase $\mathrm{NCP}_{\mathrm{p}+\mathrm{n}}$ by $12.5 \%, 26.6 \%$ and $60.2 \%$ respectively (Fig. $7 \mathrm{~b}$ ), highlighting the potential sensitivity of the system to temperature. 25 This is a much-simplified estimate that ignores the effects of thermal stratification and other complex physical phenomena that may result from increasing water temperature. However, Umoh and Thompson (1994) showed that the vertical eddy diffusivity on the Scotian Shelf reaches its annual minimum during these months, thereby restricting nutrients to the upper water column. It seems reasonable to postulate that increas-
BGD

$10,11255-11282,2013$

Carbon uptake and carbon

overconsumption in the ocean

S. E. Craig et al.

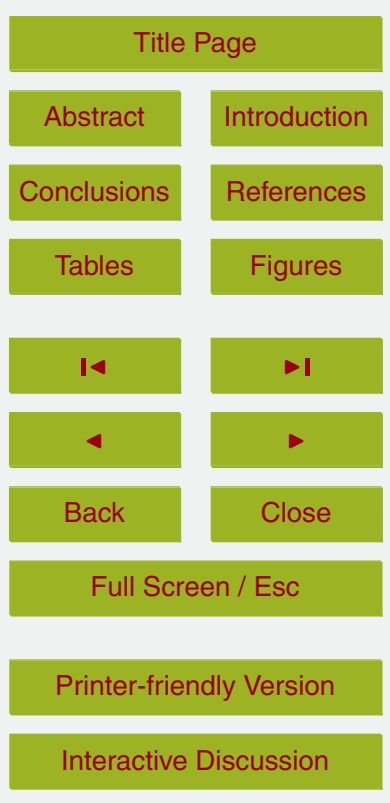

Interactive Discussion 
ing temperatures would further reduce nutrient diffusion and so enhance the role of smaller phytoplankton size classes associated with nutrient recycling (Claustre, 1994) and possible carbon overconsumption. A further amplification of the effect of temperature on the summertime phytoplankton assemblage is suggested by recent studies by

5 Taucher and colleagues (Taucher and Oschlies, 2011; Taucher et al., 2012) who postulate that nutrient recycling and phytoplankton metabolism may be elevated at higher temperatures.

\section{Conclusions}

This study has shown that numerically abundant pico- and nanophytoplankton are cor10 related with persistent uptake of carbon throughout the nutrient poor, post bloom summer months, and appear associated with carbon overconsumption. During the summer, this fraction of the phytoplankton assemblage is uncoupled from the $\mathrm{Chl}$ a standing stock, yet accounts for approximately the same amount of net community production as the spring bloom. Carbon uptake is commonly estimated using $\mathrm{C}: \mathrm{Chl}$ a ratios; how15 ever, our findings suggest that using this approach may leave $\sim 20 \%$ of biomass inventory unaccounted for. As the ocean responds to climate change, it is expected that there will be an accompanying shift in the phytoplankton community structure towards smaller cell sizes. However, the effect of this shift on the complex carbon dynamics of the Scotian Shelf, which has been characterized as a net source of carbon to the atmosphere (Shadwick et al., 2010, 2011), remains uncertain. Recent studies (Taucher and Oschlies, 2011; Taucher et al., 2012) suggested that water temperature increases predicted to occur under global warming scenarios may increase microbial loop nutrient recycling, potentially increasing the effect of the smaller cells on annual carbon uptake. It seems reasonable to postulate that these processes may occur in shelf systems worldwide and could have significant implications for estimates of annual carbon uptake. Our results also point to the potential to characterize many of these effects using remote sensing of ocean colour and sea surface temperature, and future efforts will rely
BGD

10, 11255-11282, 2013

Carbon uptake and carbon

overconsumption in the ocean

S. E. Craig et al.

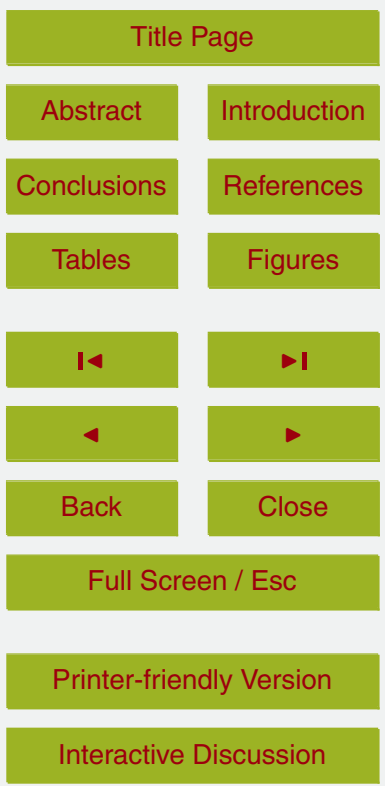


heavily on these technologies to refine our understanding of the effects of a changing

climate on global biogeochemical cycles.

\section{Supplementary material related to this article is available online at: http://www.biogeosciences-discuss.net/10/11255/2013/ 5 bgd-10-11255-2013-supplement.pdf.}

Acknowledgements. This work was supported by the Canadian Foundation for Climate and Atmospheric Sciences (CFCAS). Data from station HL2 and Bedford Basin were provided by Department of Fisheries and Oceans (DFO) Canada Atlantic Zone Monitoring Project (AZMP) and Bedford Basin Plankton Monitoring Program respectively. We thank Tim Perry, Carla Caverhill and Heidi Maas of Bedford Institute of Oceanography (BIO) for their assistance in compiling in situ and satellite data, and Kevin Pauley (BIO) for guidance on phytoplankton taxonomy.

\section{References}

Alvain, S., Moulin, C., Dandonneau, Y., and Bréon, F. M.: Remote sensing of phytoplankton groups in case 1 waters from global SeaWiFS imagery, Deep Sea Res. I, 52, 1989-2004, 2005.

Barnes, C., Irigoien, X., De Oliveira, J. A. A., Maxwell, D., and Jennings, S.: Predicting marine phytoplankton community size structure from empirical relationships with remotely sensed variables, J. Plankton Res., 33, 13-24, doi:10.1093/plankt/fbq088, 2011.

Behrenfeld, M. J., O’Malley, R. T., Siegel, D. A., McClain, C. R., Sarmiento, J. L., G. C., F., Milligan, A. J., Falkowski, P. G., Letelier, R. M., and Boss, E. S.: Climate-driven trends in contemporary ocean productivity, Nature, 444, 752-755, doi:10.1038/nature05317, 2006.

Boyce, D. G., Lewis, M. R., and Worm, B.: Global phytoplankton decline over the past century, Nature, 466, 591-596, doi:10.1038/nature09268, 2010.

Brewin, R. J. W., Devred, E., Sathyendranath, S., Lavender, S. J., and HardmanMountford, N. J.: Model of phytoplankton absorption based on three size classes, Appl. Optics, 50, 4535-4549, 2011.

Carbon uptake and carbon

overconsumption in the ocean

S. E. Craig et al.

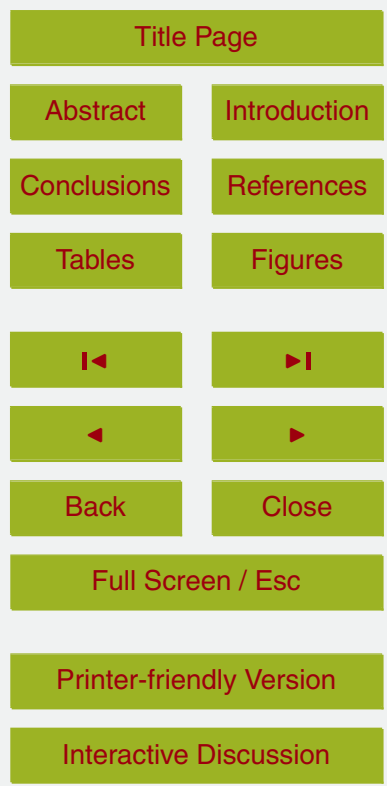


Bricaud, A., Claustre, H., Ras, J., and Oubelkheir, K.: Natural variability of phytoplanktonic absorption in oceanic waters: influence of the size structure of algal populations, J. Geophys. Res., 109, C11010, doi:10.1029/2004JC002419, 2004.

Cermeño, P., Dutkiewicz, S., Harris, R. P., Follows, M., Schofield, O., and Falkowski, P. G.: The 5 role of nutricline depth in regulating the ocean carbon cycle, P. Natl. Acad. Sci. USA, 105, 20344-20349, doi:10.1073/pnas.0811302106, 2008.

Chisholm, S. W.: Phytoplankton size, in: Primary Productivity and Biogeochemical Cycles in the Sea, edited by: Falkowski, P. G. and Woodhead, A. D., Plenum Press, New York, 1992.

Ciotti, A. M., Lewis, M. R., and Cullen, J. J.: Assessment of the relationships between dominant cell size in natural phytoplankton communities and the spectral shape of the absorption coefficient, Limnol. Oceanogr., 47, 404-417, 2002.

Ciotti, A. M. and Bricaud, A.: Retrievals of a size parameter for phytoplankton and spectral light absorption by colored detrital matter from water-leaving radiances at SeaWiFS channels in a continental shelf region off Brazil, Limnol. Oceanogr.: Methods, 4, 237-253, 2006.

Claustre, H.: The trophic status of various oceanic provinces as revealed by phytoplankton pigment signatures, Limnol. Oceanogr., 39, 1206-1210, 1994.

Craig, S. E., Jones, C. T., Li, W. K. W., Lazin, G., Horne, E., Caverhill, C., and Cullen, J. J.: Deriving optical metrics of coastal phytoplankton biomass from ocean colour, Remote Sens. Environ., 119, 72-83, doi:10.1016/j.rse.2011.12.007, 2012.

Cullen, J. J.: The deep chlorophyll maximum: Comparing vertical profiles of chlorophyll $a$, Can. J. Fish. Aquat. Sci., 39, 791-803, doi:10.1139/f82-108, 1982.

Devred, E., Sathyendranath, S., Stuart, V., and Platt, T.: A three component classification of phytoplankton absorption spectra: Application to ocean-color data, Remote Sens. Environ., 115, 2255-2266, doi:10.1016/j.rse.2011.04.025, 2011.

Falkowski, P. G., Barber, R. T., and Smetacek, V.: Biogeochemical controls and feedbacks on ocean primary production, Science, 281, 200-206, doi:10.1126/science.281.5374.200, 1998.

Fennel, K., Wilkin, J., Previdi, M., and Najjar, R.: Denitrification effects on air-sea $\mathrm{CO}_{2}$ flux in the coastal ocean: simulations for the northwest North Atlantic, Geophys. Res. Lett., 35, L24608, doi:10.1029/2008gl036147, 2008.

Finkel, Z. V., Beardall, J., Flynn, K. J., Quigg, A., Rees, T. A. V., and Raven, J. A.: Phytoplankton in a changing world: cell size and elemental stoichiometry, J. Plankton Res., 32, 119-137, doi:10.1093/plankt/fbp098, 2010.
BGD

10, 11255-11282, 2013

Carbon uptake and carbon

overconsumption in the ocean

S. E. Craig et al.

Title Page

Abstract

Introduction

Conclusions

Tables

References

Figures

14

4

Back

Full Screen / Esc

Printer-friendly Version

Interactive Discussion 
Fogg, G. E.: The phytoplanktonic ways of life, New Phytol., 118, 191-232, doi:10.1111/j.14698137.1991.tb00974.x, 1991.

Fournier, R. O., Marra, J., Bohrer, R., and Van Det, M.: Plankton dynamics and nutrient enrichment of the Scotian Shelf, J. Fish. Res. Board Can., 34, 1004-1018, 1977.

5 Greenan, B. J. W., Petrie, B. D., Harrison, W. G., and Oakey, N. S.: Are the spring and fall blooms on the Scotian Shelf related to short-term physical events?, Cont. Shelf. Res., 24, 603-625, doi:10.1016/j.csr.2003.11.006, 2004.

Hirata, T., Hardman-Mountford, N. J., Brewin, R. J. W., Aiken, J., Barlow, R., Suzuki, K., Isada, T., Howell, E., Hashioka, T., Noguchi-Aita, M., and Yamanaka, Y.: Synoptic relationships between surface Chlorophyll-a and diagnostic pigments specific to phytoplankton functional types, Biogeosciences, 8, 311-327, doi:10.5194/bg-8-311-2011, 2011.

Hoepffner, N. and Sathyendranath, S.: Bio-optical charvateristics of coastal waters - Absorption spectra of phytoplankton and pigment distribution in the western North Atlantic, Limnol. Oceanogr., 37, 1660-1679, 1992.

Hoepffner, N. and Sathyendranath, S.: Determination of the major groups of phytoplankton pigments from the absorption spectra of total particulate matter, J. Geophys. Res., 98, 2278922803, 1993.

Jiang, Z.-P., Hydes, D. J., Tyrrell, T., Hartman, S. E., Hartman, M. C., Dumousseaud, C., Padin, X. A., Skjelvan, I., and González-Pola, C.: Key controls on the seasonal and interannual variations of the carbonate system and air-sea $\mathrm{CO}_{2}$ flux in the Northeast Atlantic (Bay of Biscay), J. Geophys. Res.-Oceans, 118, 785-800, doi:10.1002/jgrc.20087, 2013.

Koeve, W.: Spring bloom carbon to nitrogen ratio of net community production in the temperate N. Atlantic, Deep-Sea Res. Pt. I, 51, 1579-1600, doi:10.1016/j.dsr.2004.07.002, 2004.

Körtzinger, A., Koeve, W., Kahler, P., and Mintrop, L.: C:N ratios in the mixed layer during the productive season in the northeast Atlantic Ocean, Deep-Sea Res. Pt. I., 48, 661-688, doi:10.1016/s0967-0637(00)00051-0, 2001.

Kyewalyanga, M. N., Platt, T., Sathyendranath, S., Lutz, V. A., and Stuart, V.: Seasonal variations in physiological parameters of phytoplankton across the North Atlantic, J. Plankton Res., 20, 17-42, doi:10.1093/plankt/20.1.17, 1998.

30 Laws, E. A., Falkowski, P. G., Smith, W. O., Ducklow, H., and McCarthy, J. J.: Temperature effects on export production in the open ocean, Global Biogeochem. Cy., 14, 1231-1246, doi:10.1029/1999gb001229, 2000.

$10,11255-11282,2013$

Carbon uptake and carbon

overconsumption in the ocean

S. E. Craig et al.

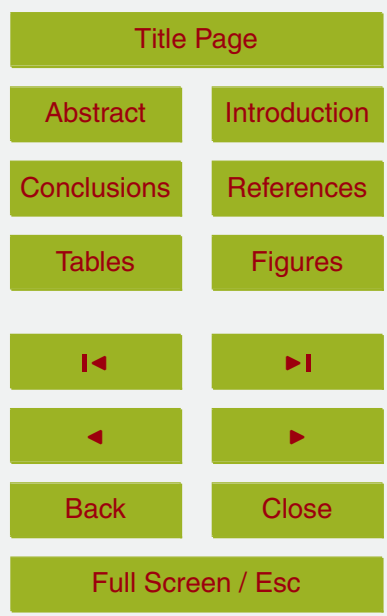

Printer-friendly Version

Interactive Discussion 
Li, W. K. W. and Dickie, P. M.: Monitoring phytoplankton, bacterioplankton, and virioplankton in a coastal inlet (Bedford Basin) by flow cytometry, Cytometry, 44, 236-246, 2001.

Li, W. K. W. and Harrison, W. G.: Chlorophyll, bacteria and picophytoplankton in ecological provinces of the North Atlantic, Deep-Sea Res. Pt. II, 48, 2271-2293, doi:10.1016/S09670645(00)00180-6, 2001.

$\mathrm{Li}, \mathrm{W}$. K. W. and Harrison, W. G.: Propagation of an atmospheric signal to phytoplankton in a small basin, Limnol. Oceanogr., 53, 1734-1745, 2008.

Li, W. K. W., Dickie, P. M., Harrison, W. G., and Irwin, B. D.: Biomass and production of bacteria and phytoplankton during the spring bloom in the western North Atlantic Ocean, Deep-Sea

10 Res. Pt. II, 40, 307-327, doi:10.1016/0967-0645(93)90019-J, 1993.

Li, W. K. W., Glen Harrison, W., and Head, E. J. H.: Coherent assembly of phytoplankton communities in diverse temperate ocean ecosystems, P. Roy. Soc. B, 273, 1953-1960, doi:10.1098/rspb.2006.3529, 2006.

Li, W. K. W., McLaughlin, F. A., Lovejoy, C., and Carmack, E. C.: Smallest Algae Thrive As the 15 Arctic Ocean Freshens, Science, 326, p. 539, doi:10.1126/science.1179798, 2009.

Margalef, R.: Life-forms of phytoplankton as survival alternatives in an unstable environment, Oceanol. Acta, 1, 493-509, 1978.

Menden-Deuer, S. and Lessard, E. J.: Carbon to volume relationships for dinoflaggelates, diatoms and other protist plankton, Limnol. Oceanogr., 45, 569-579, 2000.

20 Mitchell, B. G., Kahru, M., Wieland, J., and Stramska, M.: Determination of spectral absorption coefficients of particles, dissolved material and phytoplankton for discrete water samples, National Aeronautics and Space Administration, Greenbelt, MD, 39-67, 2002a.

Mitchell, M. R., Harrison, W. G., Pauley, K., Gagné, A., Maillet, G. L., and Strain, P.: Atlantic Zone Monitoring Program Protocol, Department of Fisheries and Oceans, Maritimes Region, $252002 b$.

Morán, X. A. G., López-Urrutia, Á., Calvo-Díaz, A., and Li, W. K. W.: Increasing importance of small phytoplankton in a warmer ocean, Glob. Change Biol, 16, 1137-1144, doi:10.1111/j.1365-2486.2009.01960.x, 2010.

Mullin, M. M., Sloan, P. R., and Eppley, R. W.: Relationship between carbon content, cell vol30 ume, and area in phytoplankton, Limnol. Oceanogr., 11, 307-311, 1966.

Osterroht, C. and Thomas, H.: New production enhanced by nutrient supply from nonRedfield remineralisation of freshly produced organic material, J. Mar. Syst., 25, 33-46, doi:10.1016/s0924-7963(00)00007-5, 2000.

Carbon uptake and carbon

overconsumption in the ocean

S. E. Craig et al.

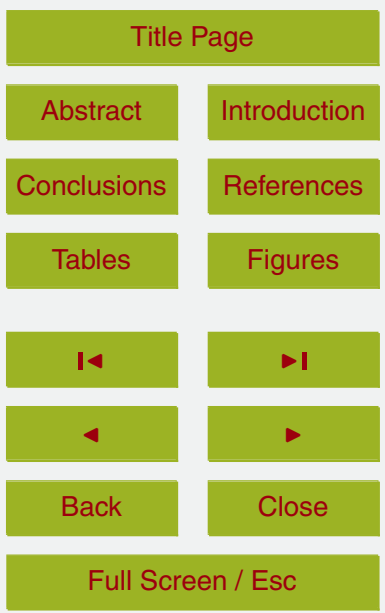

Printer-friendly Version

Interactive Discussion 
Peters, R. H.: The Ecological Importance of Body Size, Cambridge University Press, Cambridge, 1983.

Redfield, A. C., Ketchum, B. H., and Richards, F. A.: The influence of organisms on the composition of seawater, in: The Sea, edited by: Hill, M. N., Interscience, New York, 1963.

5 Riebesell, U., Körtzinger, A., and Oschlies, A.: Sensitivities of marine carbon fluxes to ocean change, P. Natl. Acad. Sci. USA, 106, 20602-20609, doi:10.1073/pnas.0813291106, 2009.

Sambrotto, R. N., Savidge, G., Robinson, C., Boyd, P., Takahashi, T., Karl, D. M., Langdon, C., Chipman, D., Marra, J., and Codispoti, L.: Elevated consumption of carbon relatve to nitrogen in the surface ocean, Nature, 363, 248-250, doi:10.1038/363248a0, 1993.

10 Serret, P., Robinson, C., Fernández, E., Teira, E., Tilstone, G., and Pérez, V.: Predicting plankton net community production in the Atlantic Ocean, Deep-Sea Res. Pt. II, 56, 941-953, doi:10.1016/j.dsr2.2008.10.006, 2009.

Shadwick, E. H. and Thomas, H.: Carbon Dioxide in the Coastal Ocean: A Case Study in the Scotian Shelf Region, in: Ocean Yearbook 25, edited by: Chircop, A., Coffen-Smout, S., and McConnell, M., Martinus Nijhoff, Leiden/Boston, 171-204, 2011.

Shadwick, E. H., Thomas, H., Comeau, A., Craig, S. E., Hunt, C. W., and Salisbury, J. E.: AirSea $\mathrm{CO}_{2}$ fluxes on the Scotian Shelf: seasonal to multi-annual variability, Biogeosciences, 7 , 3851-3867, doi:10.5194/bg-7-3851-2010, 2010.

Shadwick, E. H., Thomas, H., Azetsu-Scott, K., Greenan, B. J. W., Head, E., and Horne, E.: Seasonal variability of dissolved inorganic carbon and surface water $p \mathrm{CO}_{2}$ in the Scotian Shelf region of the Northwestern Atlantic, Mar. Chem., 124, 23-37, doi:10.1016/j.marchem.2010.11.004, 2011.

Smayda, T. J.: Harmful algal blooms: Their ecophysiology and general relevance to phytoplankton blooms in the sea, Limnol. Oceanogr., 42, 1137-1153, 1997.

Sommer, U., Stibor, H., Katechakis, A., Sommer, F., and Hansen, T.: Pelagic food web configurations at different levels of nutrient richness and their implications for the ratio fish production:primary production, Hydrobiologia, 484, 11-20, 2002.

Takahashi, T., Sutherland, S. C., Sweeney, C., Poisson, A., Metzl, N., Tilbrook, B., Bates, N., Wanninkhof, R., Feely, R. A., Sabine, C., Olafsson, J., and Nojiri, Y.: Global sea-air $\mathrm{CO}_{2}$ flux based on climatological surface ocean $p \mathrm{CO}_{2}$, and seasonal biological and temperature effects, Deep-Sea Res. Pt. II, 49, 1601-1622, doi:10.1016/S0967-0645(02)00003-6, 2002.

Taucher, J. and Oschlies, A.: Can we predict the direction of marine primary production change under global warming?, Geophys. Res. Lett., 38, L02603, doi:10.1029/2010gl045934, 2011.

BGD

10, 11255-11282, 2013

Carbon uptake and carbon

overconsumption in the ocean

S. E. Craig et al.

Title Page

Abstract

Introduction

Conclusions

Tables

References

Figures

14

4

Back

Full Screen / Esc

Printer-friendly Version

Interactive Discussion 
Taucher, J., Schulz, K. G., Dittmar, T., Sommer, U., Oschlies, A., and Riebesell, U.: Enhanced carbon overconsumption in response to increasing temperatures during a mesocosm experiment, Biogeosciences, 9, 3531-3545, doi:10.5194/bg-9-3531-2012, 2012.

Thomas, H., Ittekkot, V., Osterroht, C., and Schneider, B.: Preferential recycling of nutrients - the ocean's way to increase new production and to pass nutrient limitation?, Limnol. Oceanogr., 44, 1999-2004, 1999.

Thomas, H., Craig, S. E., Greenan, B. J. W., Burt, W., Herndl, G. J., Higginson, S., Salt, L., Shadwick, E. H., and Urrego-Blanco, J.: Direct observations of diel biological $\mathrm{CO}_{2}$ fixation on the Scotian Shelf, northwestern Atlantic Ocean, Biogeosciences, 9, 2301-2309, doi:10.5194/bg-9-2301-2012, 2012.

Toggweiler, J. R.: Oceanography - carbon overconsumption, Nature, 363, 210-211, doi:10.1038/363210a0, 1993.

Uitz, J., Claustre, H., Morel, A., and Hooker, S. B.: Vertical distribution of phytoplankton communities in open ocean: An assessment based on surface chlorophyll, J. Geophys. Res., 111, C08005, doi:10.1029/2005JC003207, 2006.

Umoh, J. U. and Thompson, K. R.: Surface heat flux, horizontal advection, and the seasonal evolution of water temperature on the Scotian Shelf, J. Geophys. Res.-Oceans, 99, 2040320416, doi:10.1029/94jc01620, 1994.

Verity, P. G., Robertson, C. Y., Tronzo, C. R., Andrews, M. G., Nelson, J. R., and Sieracki, M. E.: Relationships between cell volume and the carbon and nitrogen content of marine photosynthetic nanoplankton, Limnol. Oceanogr., 37, 1434-1446, 1992.

Zubkov, M. V. and Tarran, G. A.: High bacterivory by the smallest phytoplankton in the North Atlantic Ocean, Nature, 455, 224-226, 2008.

Carbon uptake and carbon

overconsumption in

the ocean

S. E. Craig et al.

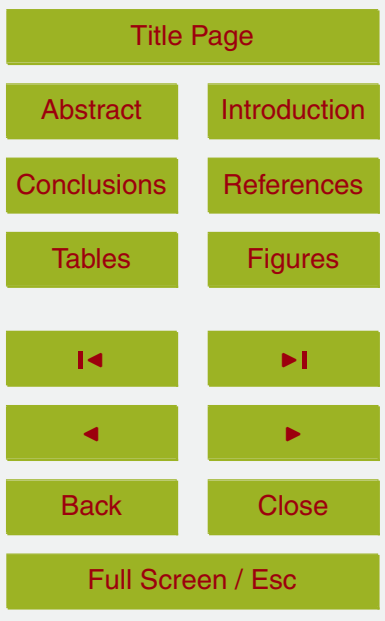

Printer-friendly Version

Interactive Discussion 
Table 1. Statistics of $\mathrm{NCP}_{\mathrm{p}}$ estimates for total phytoplankton assemblage and constituent size classes.

\begin{tabular}{llllllll}
\hline Year & & 1999 & 2000 & 2001 & 2002 & 2003 & 2004 \\
\hline$R^{2}(N)$ & tot & $0.644(12)$ & $0.603(10)$ & $0.973(5)$ & $0.029(12)$ & $0.145(12)$ & $0.367(10)$ \\
& $p+n$ & $0.838(12)$ & $0.819(12)$ & $0.356(10)$ & $0.226(12)$ & $0.002(12)$ & $0.24(12)$ \\
& dia & $0.24(12)$ & $0.944(10)$ & $0.973(5)$ & $0.007(12)$ & $0.877(12)$ & $0.931(10)$ \\
& dino & $0.108(12)$ & $0.176(10)$ & $0.04(5)$ & $0.241(12)$ & $0.253(12)$ & $0.141(10)$ \\
& $p+n+$ dia & $0.65(12)$ & $0.6(10)$ & $0.975(5)$ & $0.025(12)$ & $0.147(12)$ & $0.366(10)$ \\
Year & & 2005 & 2006 & 2007 & 2008 & 2009 & 2010 \\
\hline$R^{2}(N)$ & tot & $0.599(6)$ & $0.253(10)$ & $0.419(10)$ & $0.545(10)$ & $0.044(8)$ & $0.05(10)$ \\
& $p+n$ & $0.621(12)$ & $0.231(12)$ & $0.003(12)$ & $0.646(12)$ & $0.131(12)$ & $0.003(12)$ \\
& dia & $0.932(6)$ & $0.575(10)$ & $0.947(10)$ & $0.923(10)$ & $0(8)$ & $0.079(10)$ \\
& dino & $0.277(6)$ & $0(10)$ & $0.051(10)$ & $0.037(10)$ & $0.367(8)$ & $0.056(10)$ \\
& $p+n+$ dia & $0.595(6)$ & $0.253(10)$ & $0.422(10)$ & $0.542(10)$ & $0.042(8)$ & $0.053(10)$ \\
\hline
\end{tabular}

Definitions: tot - total; $p+n-$ picophytoplankton + nanophytoplankton; dia - diatom; dino - dinoflagellate, $N-$ number of data points. In some years there is a differing number of data points $(N)$ for $p+n$ compared with the other assemblage components. This reflects the differences in sampling strategies for each of the size classes.
10, 11255-11282, 2013

Carbon uptake and carbon

overconsumption in the ocean

\section{S. E. Craig et al}

\section{Title Page}

\section{Abstract}

Introduction

Conclusions

References

Tables

Figures

14

Back

Close

\section{Full Screen / Esc}

Printer-friendly Version

Interactive Discussion 


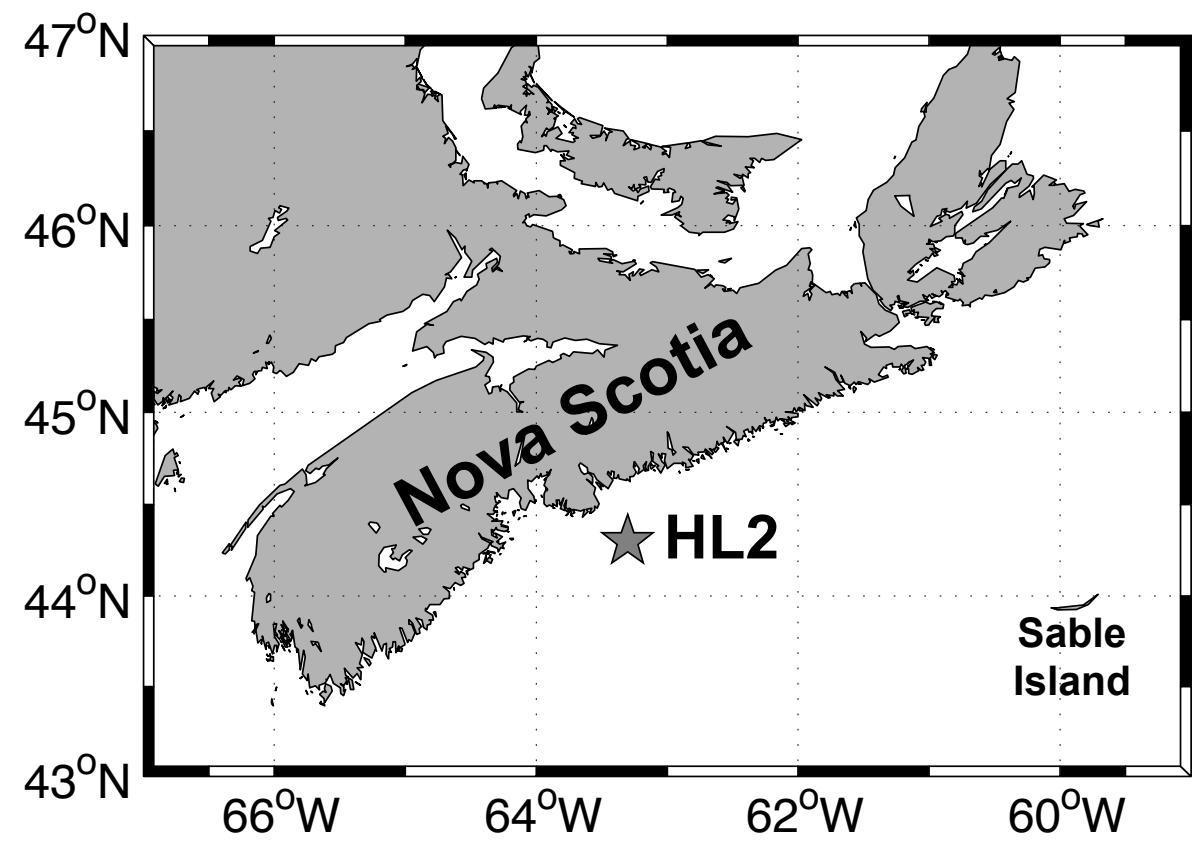

Fig. 1. Map of study area showing station HL2 on the Scotian Shelf, off the coast of Nova Scotia, eastern Canada.

\section{BGD}

10, 11255-11282, 2013

Carbon uptake and carbon

overconsumption in the ocean

\section{S. E. Craig et al.}

\section{Title Page}

\section{Abstract}

Introduction

Conclusions

References

Tables

Figures

14

$\rightarrow$

4

Back

Close

\section{Full Screen / Esc}

Printer-friendly Version 

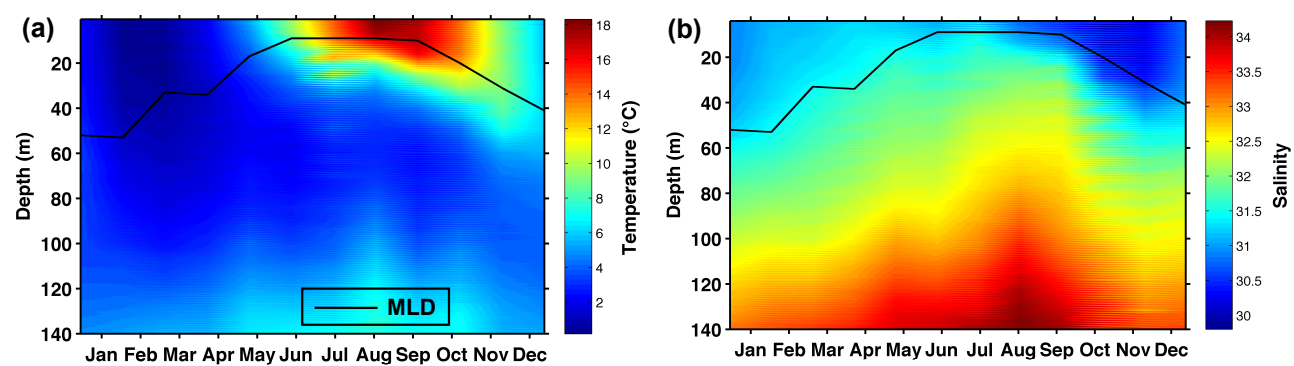

BGD

10, 11255-11282, 2013

Carbon uptake and carbon

overconsumption in the ocean
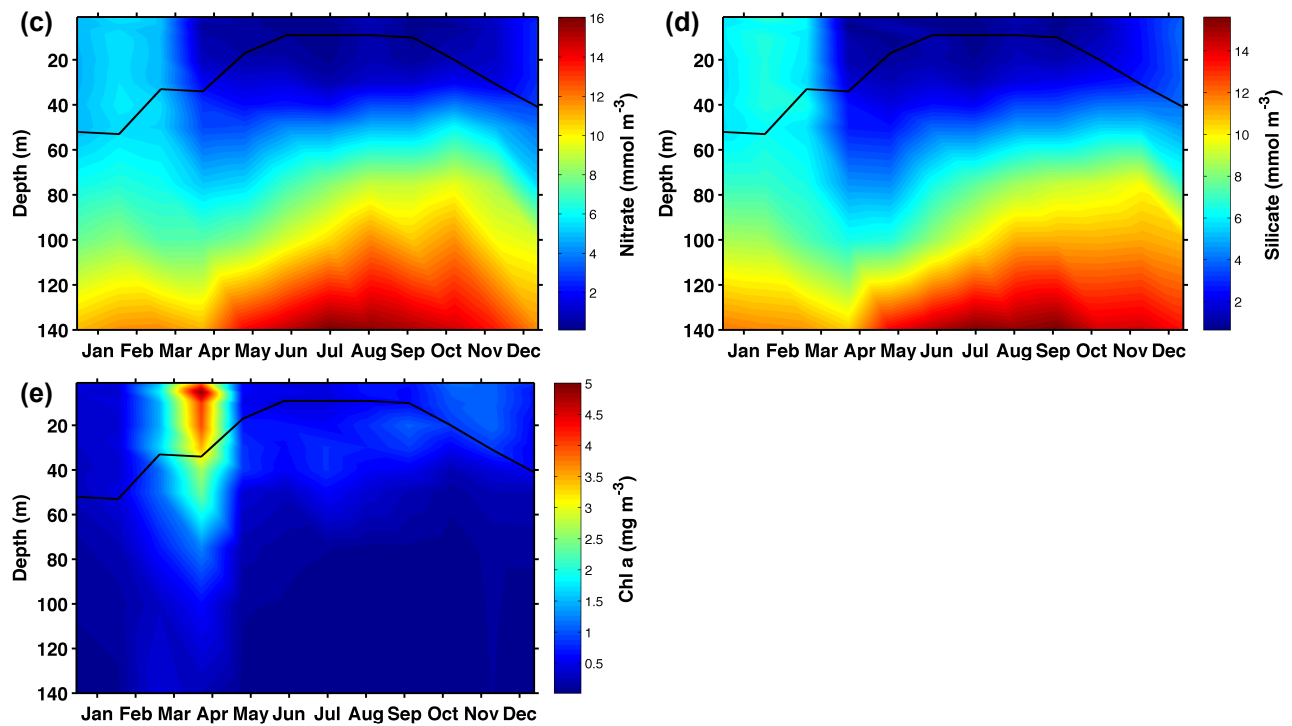

\section{S. E. Craig et al.}

\section{Title Page}

\section{Abstract}

Conclusions

\section{Tables}

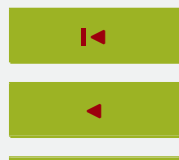

Back
Introduction

References

Figures

$>$ I

$\checkmark$

Close

\section{Full Screen / Esc}

Printer-friendly Version

Interactive Discussion 


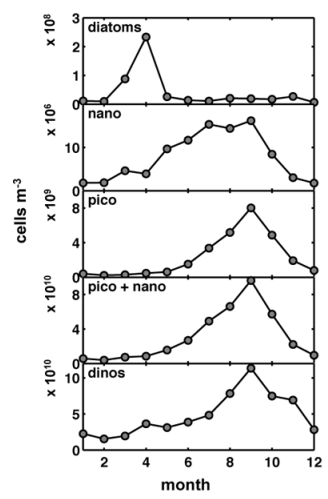

Fig. 3(a)

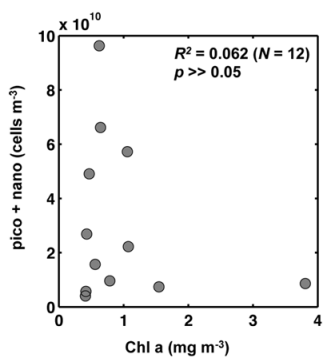

Fig. 3(c)

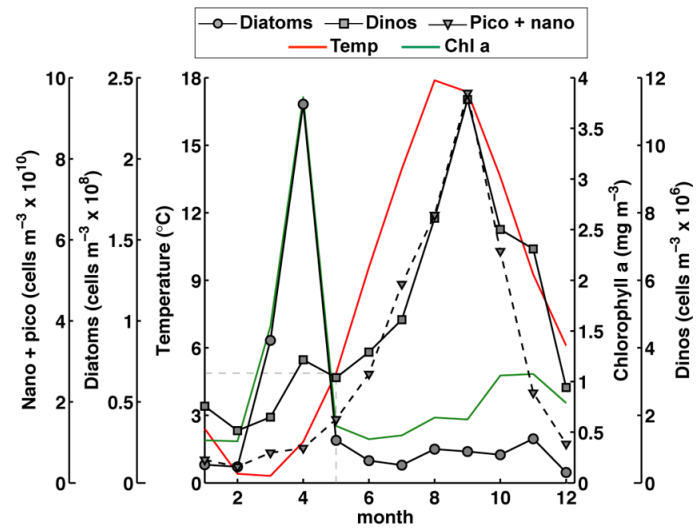

Fig. 3(b)

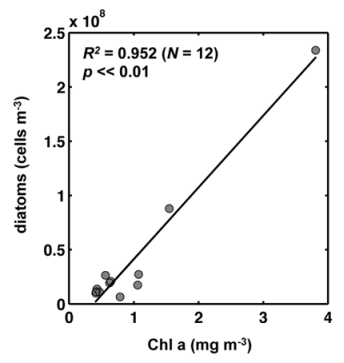

Fig. 3(d)

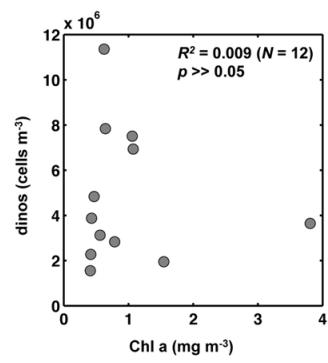

Fig. 3(e)

Fig. 3. Climatological seasonal patterns in phytoplankton succession. (a) Seasonal cycle of diatoms, nanophytoplankton (nano), picophytoplankton (pico), pico and nano combined (pico + nano) and dinoflagellates (dinos). (b) Seasonal cycle of temperature (red line), Chl a (green line), diatoms (grey circles), dinoflagellates (grey squares) and pico + nano (grey triangles). The grey dotted lines indicate the collapse of the spring bloom in May at $\sim 5^{\circ} \mathrm{C}$, the shoaling of the mixed layer depth and the transition to a phytoplankton assemblage numerically dominated by smaller cells. (c-e) pico + nano, diatom and dino versus $\mathrm{Chl} a$.

10, 11255-11282, 2013

Carbon uptake and carbon

overconsumption in the ocean

S. E. Craig et al

\section{Title Page}

Abstract Introduction

Conclusions References

Tables

Figures

14

$\rightarrow 1$

4

Back

Close

Full Screen / Esc

Printer-friendly Version

Interactive Discussion 


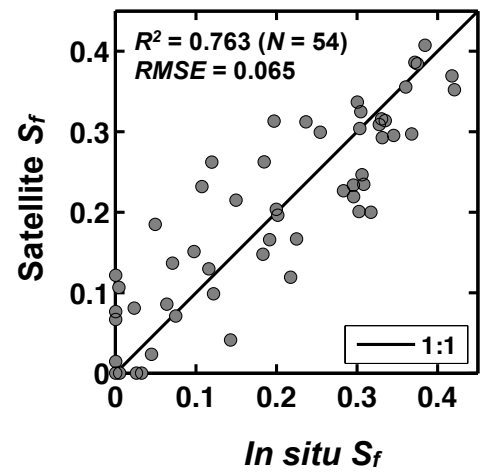

Fig. 4(a)

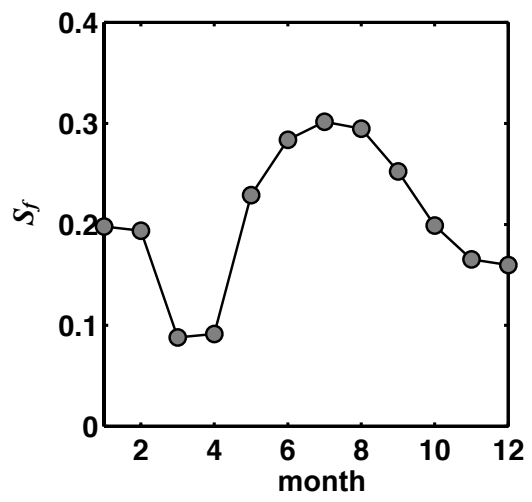

Fig. 4 (b)

Fig. 4. (a) In situ and satellite derived size factor, $S_{f}$ (dimensionless). In situ $S_{f}$ was derived from filterpad measurements of $a_{\mathrm{ph}}(\lambda)$ and satellite $S_{f}$ from satellite-derived $a_{\mathrm{ph}}(\lambda)$. (b) Satellite $S_{f}$ derived size factor from monthly climatological $R_{\mathrm{rs}}(\lambda)$. Values close to 0 indicate an assemblage dominated by large cells.

\section{BGD}

$10,11255-11282,2013$

Carbon uptake and

carbon

overconsumption in

the ocean

\section{S. E. Craig et al}

\section{Title Page}

\section{Abstract}

Introduction

Conclusions

References

Tables

Figures

14

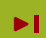

4

Back

Close

Full Screen / Esc

Printer-friendly Version

Interactive Discussion 

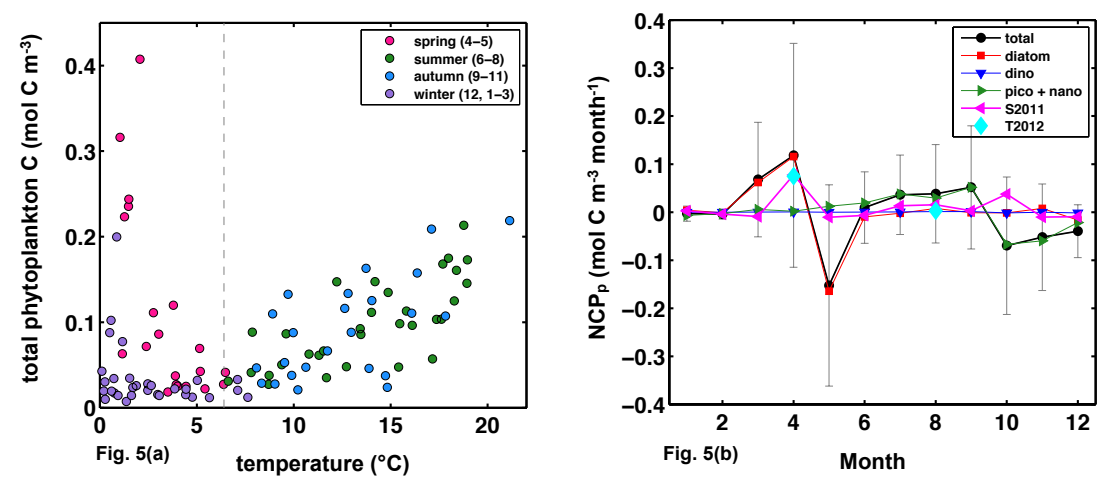

BGD

10, 11255-11282, 2013

Carbon uptake and

carbon

overconsumption in

the ocean

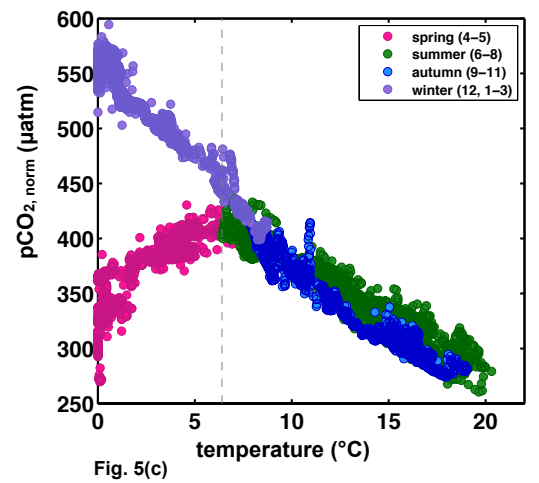

S. E. Craig et al.

\section{Title Page}

Abstract

Introduction

Conclusions

References

Tables

Figures

14

4

Fig. 5. Seasonal carbon dynamics. (a) Relationship between total phytoplankton carbon and water temperature. The grey dotted line corresponds to the month of May, the collapse of the spring bloom and the transition to an assemblage numerically dominated by smaller cells. Seasons and corresponding months are indicated in the legend. (b) Seasonal pattern of $\mathrm{NCP}_{\mathrm{p}}$. The error bars represent one standard deviation of total $\mathrm{NCP}_{\mathrm{p}}$, calculated from the mean of 19992011, and indicate the high degree of interannual variability. S2011 - Shadwick et al. (2011), T2012 Thomas et al. (2012) (c) Composite seasonal cycle of $p \mathrm{CO}_{2}$, norm constructed from data spanning 2007-2009 and redrawn after Shadwick et al. (2011).

$\rightarrow 1$

$\rightarrow$

Close

Full Screen / Esc

Printer-friendly Version

Interactive Discussion 


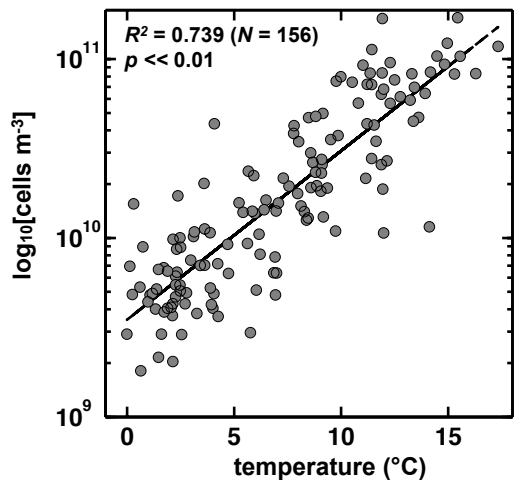

Fig. 6(a)

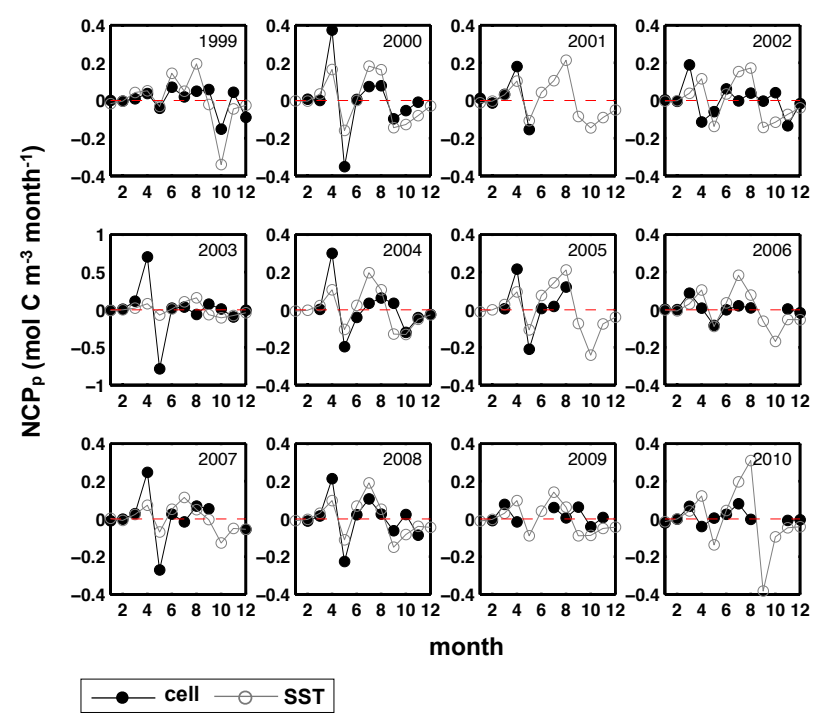

Fig. 6(b)

Fig. 6. Relationship between $\mathrm{NCP}_{p+n}$ and temperature. (a) Annual maximum $\mathrm{NCP}_{p+n}$ as a function of annual maximum temperature. The red point was omitted from the regression as it lay $>2.5$ standard deviations from a robustly fitted model line. (b) The effect of increasing temperature on estimated $\mathrm{NCP}_{p+n}$. This was achieved by adding increments of $0.5,1,2^{\circ} \mathrm{C}$ to the climatological temperature cycle.

BGD

$10,11255-11282,2013$

Carbon uptake and

carbon

overconsumption in

the ocean

S. E. Craig et al.

\section{Title Page}

Abstract

Introduction

Conclusions

References

Tables

Figures

14

I

4

Back

Close

Printer-friendly Version

Interactive Discussion 


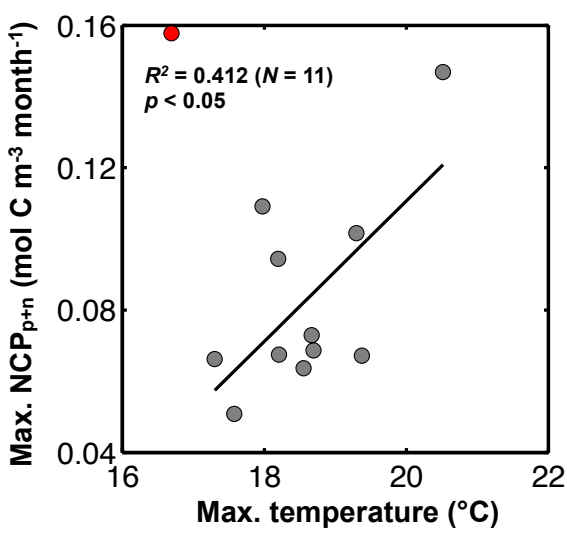

Fig. $7(a)$

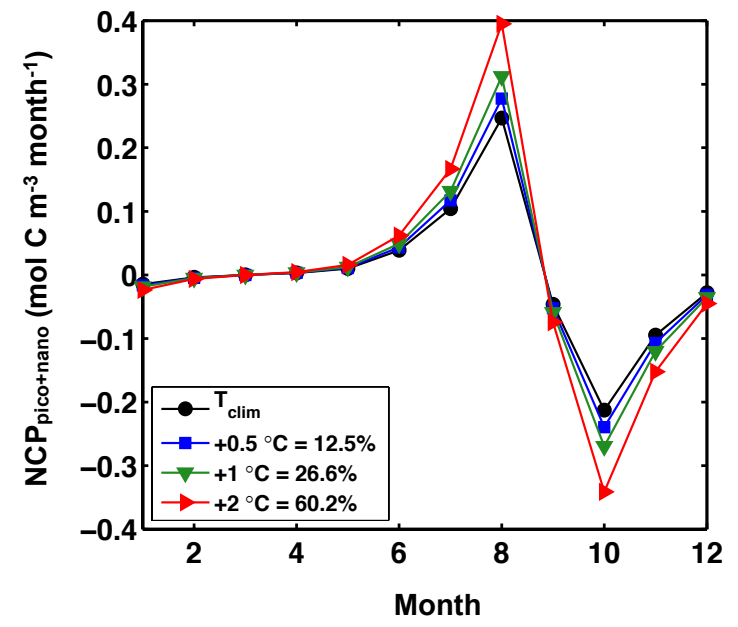

Fig. 7 (b)
10, 11255-11282, 2013

Carbon uptake and carbon

overconsumption in

the ocean

S. E. Craig et al

\section{Title Page}

Abstract

Introduction

Conclusions

References

Tables

Figures

14

$\rightarrow 1$

4

Back

Close

indicates zero $\mathrm{NCP}_{\mathrm{p}}$.

\section{Full Screen / Esc}

Printer-friendly Version

Interactive Discussion 